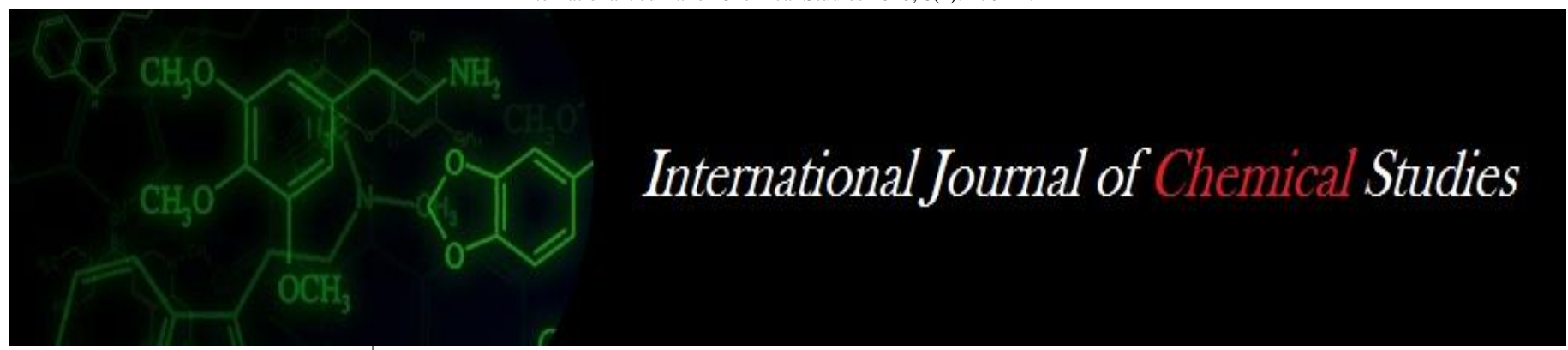

P-ISSN: 2349-8528

E-ISSN: 2321-4902

www.chemijournal.com

IJCS 2020; 8(1): 2704-2712

(C) 2020 IJCS

Received: 16-11-2019

Accepted: 18-12-2019

\section{Divya RK}

Department of Agronomy,

College of Agriculture, Orissa

University of Agriculture and

Technology, Bhubaneswar,

Odisha, India

\section{Behera B}

Department of Agronomy, College of Agriculture, Orissa University of Agriculture and Technology, Bhubaneswar, Odisha, India

\section{Jena SN}

Department of Agronomy, College of Agriculture, Orissa University of Agriculture and Technology, Bhubaneswar, Odisha, India

\section{Corresponding Author:}

\section{Divya RK}

Department of Agronomy, College of Agriculture, Orissa University of Agriculture and Technology, Bhubaneswar, Odisha, India

\section{Effect of planting patterns and weed management practices on weed dynamics and nutrient mining in runner bean (Phaseolus coccineus L.) + Maize (Zea mays L.) intercropping}

\author{
Divya RK, Behera B and Jena SN
}

DOI: https://doi.org/10.22271/chemi.2020.v8.i1ao.8678

\begin{abstract}
A field experiment entitled "Planting pattern and weed management in maize (Zea mays L.) + runner bean (Phaseolus coccineus L.) intercropping system" was conducted during the rabi season of 2016-17 at Agronomy Main Research Farm, Bhubaneswar. The experiment was laid out in split plot design with planting patterns in the main plot and weed management practices in the sub plot. 'Shriram 9220' maize hybrid and 'Raikia local' variety of runnerbean were used as test crops. The study revealed that $\mathrm{P}_{4-}$ maize $100 \%+$ runner bean $100 \%$ in the same row recorded the minimum weed density and dry weight and maximum weed smothering efficiency. While, weed management practices, $\mathrm{W}_{3}$-Pendimethalin $1.0 \mathrm{~kg} / \mathrm{ha}$ +1 manual weeding also recorded the minimum weed density and dry weight and maximum weed control efficiency. Significantly higher nutrient of content in the maize grain and stover was recorded in maize $100 \%$ + runner bean $50 \%$ in separate rows among planting patterns and $\mathrm{W}_{3}$-pendimethalin 1.0 $\mathrm{kg} / \mathrm{ha}+$ one manual weeding at 25 DAS among weed management practices. For runner bean, maize $100 \%+$ runner bean $100 \%$ in same row gave significantly higher pod and haulm nutrient content. However, the maximum uptake of $\mathrm{N}, \mathrm{P}$ and $\mathrm{K}$ was in sole crops of runner bean and maize respectively due to its higher yield.
\end{abstract}

Keywords: Planting patterns, weed management, weed dynamics, nutrient content, nutrient uptake

\section{Introduction}

Maize (Zea mays L.) is the world's third most important cereal crop after wheat and rice. It is also one of the most versatile crops grown throughout the tropical as well as temperature regions of the world. Maize is an exhaustive crop with high nutrient requirement and hence, it is heavily fertilized. In addition, its' widely spaced rows makes it congenial for the emergence of weeds. This could impair the early crop growth and vigor which may ultimately affect the yield because; maize is highly susceptible to weed competition until it reaches the knee high stage which is 2-6 weeks after sowing. Hand weeding is highly efficient as it gives $100 \%$ weed control but, is expensive, labor intensive and highly time consuming. Hence, chemical weed control is considered to be a convenient method to suppress weed growth especially in the early growth stages in order to achieve healthy crop stand and is also cost effective.

The commonly used herbicides in maize include pre-emergent herbicides like atrazine, simazine, pendimethalin, alachlor and also post emergent application of 2,4-D. The triazine group herbicides like atrazine and simazine are highly effective in controlling wide spectrum of weeds. However, they are highly persistent in nature which varies from 6-9 months or more depending upon the dose, soil type, rainfall, organic matter, temperature and other environmental conditions. This may cause matter of concern because of residual toxicity to the subsequent crops and also, may pose risk of contamination of food. Also, continuous use of herbicides with similar mode of action may cause build-up of tolerance in weeds reducing their sensitivity to the herbicides. (Patel et al., 2006) ${ }^{[10]}$. Hence, alternative weed management strategies may help to minimize herbicide application rate and reduce the cost of weed control (Coble, 1994) ${ }^{[5]}$. Intercropping with other short duration and short stature crops which have fast early growth habit may be one of the easiest method of weed management in a widely spaced crop like maize. 
Also, maize + legume intercropping system also improves soil health, conserves soil moisture and increases total out turn (Padhi and Panigrahi, 2006) ${ }^{[9]}$.

Runner bean (Phaseolus coccineus L.) or called as the "proto pallar" in the central - southern part of Chile. In India, it is grown in the lower elevations of hilly areas (Kaloo, 1993) ${ }^{[8]}$. The tribals of north-eastern ghat zone of Orissa grow this short duration crop under rainfed conditions to get early income in the season (Behera et al., 1998) ${ }^{[1]}$. The seeds of the plant may either be used fresh or as dried beans. The young pods are edible as a whole as a vegetable.

Runner bean has a widely spreading canopy which covers the soil surface and protects the soil from soil erosion and also reduces the weed infestation in early stages and also reduces the herbicide requirement when intercropped with maize. However, besides application of herbicides to control weeds in this intercropping system, planting pattern of the component species varied by their sowing proportions also seems to play a role in the effectivity of the intercropping system in weed growth suppression. Just like how, the application of different herbicides affect the weed species diversity and community structure in the field. Similarly, varying sown proportions affect the weed dynamics by affecting their number and their dry matter production. This also affects the utilization of natural resources when compared to sole cropping (Ghanbari-Bonjar, 2000) ${ }^{[6]}$.

\section{Materials and methods}

\section{Location and duration of study}

The field experiment was conducted during rabi season of 2016-17 at Agronomy Main Research Farm, Orissa University of Agriculture and Technology, Bhubaneswar- 751 003, Odisha, India. The location has latitude and longitude of $20^{\circ} 15^{\prime} \mathrm{N}$ and $85^{\circ} 52^{\prime} \mathrm{E}$, respectively, with an altitude of 25.9 mabove mean sea level. It is situated at about $64 \mathrm{~km}$ away from the Bay of Bengal. The station falls under the East and South Eastern Coastal Plain Agro-climatic Zone (NARP) of Odisha with Moisture Deficit Index (MDI) value of 0 to 20 and length of growing season of 180 to 210 days. Maize and runner bean were sown simultaneously sown on 13th November, 2016. Harvesting of runner bean was carried out in two subsequent pickings on 27th January, 2017 and 6th February, 2017. Maize was harvested on 13th March, 2017.

\section{Experimental Design and treatments}

The experiment was laid out in a split plot design with six planting patterns in the main plot and five weed management practices in the sub plot and replicates twice. 'Shriram 9220'maize hybrid and 'Raikia local' variety of runner bean were taken as test crops in the experiment.

The six planting patterns included $\mathrm{P}_{1}$ - sole maize, $\mathrm{P}_{2^{-}}$sole runner bean, $\mathrm{P}_{3^{-}}$maize $100 \%$ + runner bean $100 \%$ in separate rows in 2:2 row ratio, $\mathrm{P}_{4}$ - maize $100 \%$ + runner bean $100 \%$ in the same row, $\mathrm{P}_{5}-$ maize $100 \%+$ runner bean $50 \%$ in separate rows in 2:1 row ratio and $\mathrm{P}_{6}$ - maize $100 \%+$ runner bean $50 \%$ in the same row.

The five weed management practices included $\mathrm{W}_{1^{-}}$ Pendimethalin at $1 \mathrm{~kg} / \mathrm{ha}$ (pre- emergence), $\mathrm{W}_{2}$ - Metribuzin at $0.03 \mathrm{~kg} / \mathrm{ha}$ (pre- emergence), $\mathrm{W}_{3^{-}}$Pendimethalin at $1 \mathrm{~kg} / \mathrm{ha}$ (pre- emergence) + one manual weeding at $25 \mathrm{DAS}, \mathrm{W}_{4-}$ Hoeing and weeding at 21 DAS and 40 DAS and $\mathrm{W}_{5^{-}}$weedy check.

\section{Statistical analysis}

The recorded data was analyzed using analysis of variance (ANOVA) and tested for significance using the student's ttest.

\section{Results}

\section{Weed dynamics}

Floristic composition of weeds

Twelve species of weeds including five grasses, one sedge and six broad leaved weeds were recorded in the experimental site (Table 1).

Table 1: Floristic composition of weeds in the experimental site

\begin{tabular}{|c|c|c|c|}
\hline S. No. & Common name & Scientific name & Family \\
\hline \multicolumn{4}{|c|}{ Grassy weeds } \\
\hline 1. & Bermuda grass & Cynodon dactylon (L.) Pers. & Poaceae \\
\hline 2. & Crow-foot grass & Dactyloctenium aegyptium (L.) Willd. & Poaceae \\
\hline 3. & Large crab grass & Digitaria sanguinalis L. & Poaceae \\
\hline 4. & Jungle rice & Echinocloa colona $(\mathrm{L}$.$) Link.$ & Poaceae \\
\hline 5. & Goose grass, Wire grass, Wild ragi & Eleusine indica (L.) Gaertn. & Poaceae \\
\hline \multicolumn{4}{|c|}{ Sedges } \\
\hline 6. & Purple nutsedge & Cyperus rotundus $\mathrm{L}$. & Cyperaceae \\
\hline \multicolumn{4}{|c|}{ Broad leaved weeds } \\
\hline 7. & Wild mustard & Cleome rutidosperma DC. & Cleomaceae \\
\hline 8. & Wild mustard & Cleome viscosa $\mathrm{L}$. & Cleomaceae \\
\hline 9. & Bengal dayflower, tropical spiderwort, wandering Jew & Commelina benghalensis L. & Commelinaceae \\
\hline 10. & Tiger foot morning glory & Ipomoea pes-tigridis L. & Convolvulaceae \\
\hline 11. & Chocolate weed & Melochia corchorifolia $\mathrm{L}$. & Malvaceae \\
\hline 12. & Horse purslane & Trianthema portulacastrum $\mathrm{L}$. & Aizoaceae \\
\hline
\end{tabular}

\section{Density of grassy weeds}

At 15 DAS, $100 \%$ maize $+50 \%$ runner bean in the same row proved the best with the minimum grassy weed density of $56.7 / \mathrm{m}^{2}$ and other treatments recorded significantly higher density of grassy weeds. Maize and runner bean at different population mixtures sown with the same row significantly less grassy weed density than that sown in different rows.

Among the weed management practices, pendimethalin 1.0 $\mathrm{kg} / \mathrm{ha}+$ one manual weeding recorded the minimum grassy weed density of $25.0 / \mathrm{m}^{2}$ and pendimethalin $1.0 \mathrm{~kg} / \mathrm{ha}$ alone remained statistically at par with it. Pendimethalin $1.0 \mathrm{~kg} / \mathrm{ha}$ and metribuzin $0.03 \mathrm{~kg} / \mathrm{ha}$ remained equally effective in reducing grassy weed density per $\mathrm{m}^{2}$.

At subsequent stages, sole runner bean recorded significantly less grassy weed density than sole maize, except at 45 DAS, where both were statistically at par. At 45 and 75 DAS, intercropping systems except $100 \%$ maize $+50 \%$ runner bean in the same row recorded higher grassy weed density than sole crops. At harvest, sole crop of maize recorded the maximum grassy weed density. 
At 45 and 75 DAS and harvest, all weed management practices recorded significantly less grassy weed density than the weedy check. Pendimethalin $1.0 \mathrm{~kg} / \mathrm{ha}+$ one manual weeding at 25 DAS proved to be the most effective and recorded the minimum grassy weed density at 45 DAS, 75 DAS and at harvest and pendimethalin $1.0 \mathrm{~kg} / \mathrm{ha}$ alone remained at par only at 45 DAS (Table 2.).

\section{Density of sedges}

Sedge density was the minimum among the three categories of weeds. Planting patterns failed to influence sedge population at all stages except at harvest, when $100 \%$ maize + $50 \%$ runner bean in the same row recorded the minimum sedge density (Table 3.).
Weed management practices failed to cause variation in sedge density at 15 and 45 DAS. At 45 DAS and at harvest, the weed management practices recorded significantly less sedge density than weedy check.

\section{Density of broad leaved weeds}

No definite trend was noted with respect to effect of planting patterns on the density of broad leaved weeds (Table 4.).

Among weed management practices, pendimethalin $1.0 \mathrm{~kg} / \mathrm{ha}$ + one manual weeding proved the most effective in controlling broad leaved weeds and recorded the minimum density of broad leaved. Only at 15 DAS, metribuzine 0.03 $\mathrm{kg} / \mathrm{ha}$ remained at par with it.

Table 2: Density of grassy weeds (number $/ \mathrm{m}^{2}$ ) as influenced by various treatments

\begin{tabular}{|c|c|c|c|c|}
\hline Treatment & 15 DAS & 45 DAS & 75 DAS & Harvest \\
\hline \multicolumn{5}{|c|}{ Planting pattern } \\
\hline $\mathrm{P}_{1}$-Sole $\mathrm{Mz}$ & $11.0(120.0)$ & $4.8(22.1)$ & $5.4(28.1)$ & $7.3(52.3)$ \\
\hline $\mathrm{P}_{2}$-Sole $\mathrm{Rb}$ & $10.8(115.6)$ & $4.2(16.6)$ & $3.6(11.9)$ & $3.1(8.6)$ \\
\hline $\mathrm{P}_{3}-\mathrm{Mz} 100 \%+\mathrm{Rb} 100 \%(2: 2)$ in separate rows & $12.5(155.2)$ & $6.7(43.8)$ & $6.4(39.9)$ & $5.9(33.8)$ \\
\hline $\mathrm{P}_{4}-\mathrm{Mz} 100 \%+\mathrm{Rb} 100 \%$ in the same row & $10.0(99.0)$ & $5.0(24.0)$ & $4.9(23.0)$ & $4.2(16.6)$ \\
\hline $\mathrm{P}_{5}-\mathrm{Mz} 100 \%+\mathrm{Rb} 50 \%$ (2:1) in separate rows & $12.5(155.2)$ & $8.0(63.0)$ & $7.4(53.7)$ & $6.6(42.5)$ \\
\hline $\mathrm{P}_{6}-\mathrm{Mz} 100 \%+\mathrm{Rb} 50 \%$ in the same row & $7.6(56.7)$ & $4.7(21.1)$ & $5.0(9.8)$ & $4.7(21.1)$ \\
\hline SEm \pm & 0.6 & 0.4 & 0.2 & 0.2 \\
\hline $\mathrm{CD}(\mathrm{P}=0.05)$ & 2.4 & 1.5 & 0.6 & 0.7 \\
\hline \multicolumn{5}{|c|}{ Weed management } \\
\hline $\mathrm{W}_{1}$-Pendimethalin $1.0 \mathrm{~kg} / \mathrm{ha}$ & $6.1(36.2)$ & $2.2(3.8)$ & $3.3(9.8)$ & $3.5(11.2)$ \\
\hline $\mathrm{W}_{2}$-Metribuzin $0.03 \mathrm{~kg} / \mathrm{ha}$ & $7.2(50.8)$ & $5.7(31.5)$ & $6.5(41.2)$ & $7.1(49.4)$ \\
\hline $\mathrm{W}_{3}$-Pendimethalin $1.0 \mathrm{~kg} / \mathrm{ha}+1 \mathrm{MW}$ at $25 \mathrm{DAS}$ & $5.1(25.0)$ & $1.8(2.2)$ & $2.7(6.3)$ & $1.7(1.8)$ \\
\hline $\mathrm{W}_{4-}$ Hoeing and weeding at 21 and 40 DAS & $17.6(308.7)$ & $4.3(17.5)$ & $4.4(18.3)$ & $6.2(37.4)$ \\
\hline $\mathrm{W}_{5}$-Weedy check & $17.9(319.4)$ & $13.9(192.2)$ & $9.1(81.8)$ & $7.9(61.4)$ \\
\hline SEm \pm & 0.4 & 0.3 & 0.1 & 0.2 \\
\hline $\mathrm{CD}(\mathrm{P}=0.05)$ & 1.4 & 1.0 & 0.4 & 0.6 \\
\hline
\end{tabular}

*Original values within parentheses and $\sqrt{x+1}$ transformed values outside parentheses

$\mathrm{Mz}$ - Maize, Rb - Runner bean, DAS- Days after sowing, MW- manual weeding

Table 3: Density of sedges $\left(\right.$ per $\mathrm{m}^{2}$ ) as influenced by various treatments

\begin{tabular}{|c|c|c|c|c|}
\hline Treatment & 15 DAS & 45 DAS & 75 DAS & Harvest \\
\hline \multicolumn{5}{|c|}{ Planting pattern } \\
\hline $\mathrm{P}_{1}$-Sole $\mathrm{Mz}$ & $1.3(0.7)$ & $1.1(0.2)$ & $1.3(0.7)$ & $1.3(0.7)$ \\
\hline $\mathrm{P}_{2}$-Sole $\mathrm{Rb}$ & $1.6(1.5)$ & $1.2(0.4)$ & $1.2(0.4)$ & $1.1(0.2)$ \\
\hline $\mathrm{P}_{3}-\mathrm{Mz} 100 \%+\mathrm{Rb} 100 \%$ (2:2) in separate rows & $1.2(0.4)$ & $1.0(0.0)$ & $1.2(0.4)$ & $1.2(0.5)$ \\
\hline $\mathrm{P}_{4}-\mathrm{Mz} 100 \%+\mathrm{Rb} 100 \%$ in the same row & $1.0(0.0)$ & $1.2(0.4)$ & $1.1(0.2)$ & $1.1(0.2)$ \\
\hline $\mathrm{P}_{5}-\mathrm{Mz} 100 \%+\mathrm{Rb} 50 \%$ (2:1) in separate rows & $1.5(1.2)$ & $1.2(0.4)$ & $1.5(1.2)$ & $1.5(1.2)$ \\
\hline $\mathrm{P}_{6}-\mathrm{Mz} 100 \%+\mathrm{Rb} 50 \%$ in the same row & $1.6(1.8)$ & $1.2(0.4)$ & $1.4(0.9)$ & $1.0(0.0)$ \\
\hline $\mathrm{SEm} \pm$ & 0.2 & 0.1 & 0.1 & 0.1 \\
\hline $\mathrm{CD}(\mathrm{P}=0.05)$ & NS & NS & NS & 0.2 \\
\hline \multicolumn{5}{|c|}{ Weed management } \\
\hline $\mathrm{W}_{1}$-Pendimethalin $1.0 \mathrm{~kg} / \mathrm{ha}$ & $1.3(0.7)$ & $1.1(0.2)$ & $1.1(0.2)$ & $1.0(0.0)$ \\
\hline $\mathrm{W}_{2}$-Metribuzin $0.03 \mathrm{~kg} / \mathrm{ha}$ & $1.5(1.2)$ & $1.3(0.7)$ & $1.1(0.2)$ & $1.0(0.0)$ \\
\hline $\mathrm{W}_{3}$-Pendimethalin $1.0 \mathrm{~kg} / \mathrm{ha}+1 \mathrm{MW}$ at $25 \mathrm{DAS}$ & $1.0(0.0)$ & $1.4(0.9)$ & $1.1(0.2)$ & $1.1(0.2)$ \\
\hline $\mathrm{W}_{4-}$ Hoeing and weeding at 21 and 40 DAS & $1.7(1.8)$ & $1.0(0.0)$ & $1.1(0.2)$ & $1.3(0.7)$ \\
\hline $\mathrm{W}_{5}$-Weedy check & $1.4(0.9)$ & $1.0(0.0)$ & $2.1(3.4)$ & $1.7(1.8)$ \\
\hline $\mathrm{SEm} \pm$ & 0.2 & 0.1 & 0.2 & 0.1 \\
\hline $\mathrm{CD}(\mathrm{P}=0.05)$ & NS & NS & 0.5 & 0.2 \\
\hline
\end{tabular}

*Original values within parentheses and $\sqrt{x+1}$ transformed values outside parentheses

$\mathrm{Mz}$ - Maize, $\mathrm{Rb}$ - Runner bean, DAS- Days after sowing, MW- manual weeding 
Table 4: Density of broad leaved weeds (per $\mathrm{m}^{2}$ ) as influenced by various treatments

\begin{tabular}{|c|c|c|c|c|}
\hline Treatment & 15 DAS & 45 DAS & 75 DAS & Harvest \\
\hline \multicolumn{5}{|c|}{ Planting pattern } \\
\hline $\mathrm{P}_{1}$-Sole $\mathrm{Mz}$ & $5.5(29.2)$ & $5.5(29.2)$ & $2.8(6.8)$ & $3.3(9.8)$ \\
\hline $\mathrm{P}_{2}$-Sole $\mathrm{Rb}$ & $5.5(29.2)$ & $4.1(15.8)$ & $2.5(5.2)$ & $1.8(2.2)$ \\
\hline $\mathrm{P}_{3}-\mathrm{Mz} 100 \%+\mathrm{Rb} 100 \%(2: 2)$ in separate rows & $5.7(31.4)$ & $5.2(26.1)$ & $2.5(5.2)$ & $2.6(5.7)$ \\
\hline $\mathrm{P}_{4}-\mathrm{Mz} 100 \%+\mathrm{Rb} 100 \%$ in the same row & $2.8(6.8)$ & $3.7(12.7)$ & $2.8(6.8)$ & $1.3(0.7)$ \\
\hline $\mathrm{P}_{5}-\mathrm{Mz} 100 \%+\mathrm{Rb} 50 \%$ (2:1) in separate rows & $5.0(24.0)$ & $4.8(22.1)$ & $3.4(10.5)$ & $2.9(7.4)$ \\
\hline $\mathrm{P}_{6}-\mathrm{Mz} 100 \%+\mathrm{Rb} 50 \%$ in the same row & $4.5(19.2)$ & $4.6(20.1)$ & $2.2(3.8)$ & $1.8(2.2)$ \\
\hline SEm \pm & 0.4 & 0.6 & 0.1 & 0.3 \\
\hline $\mathrm{CD}(\mathrm{P}=0.05)$ & 1.3 & 2.4 & 0.4 & 1.2 \\
\hline \multicolumn{5}{|c|}{ Weed management } \\
\hline $\mathrm{W}_{1}$-Pendimethalin $1.0 \mathrm{~kg} / \mathrm{ha}$ & $5.3(27.1)$ & $5.2(26.1)$ & $3.2(9.2)$ & $2.4(4.7)$ \\
\hline $\mathrm{W}_{2}$-Metribuzin $0.03 \mathrm{~kg} / \mathrm{ha}$ & $4.2(16.6)$ & $5.0(24.0)$ & $2.9(7.4)$ & $2.6(5.7)$ \\
\hline $\mathrm{W}_{3}$-Pendimethalin $1.0 \mathrm{~kg} / \mathrm{ha}+1 \mathrm{MW}$ at $25 \mathrm{DAS}$ & $4.1(15.8)$ & $2.1(3.4)$ & $2.5(5.2)$ & $1.3(0.6)$ \\
\hline $\mathrm{W}_{4-}$ Hoeing and weeding at 21 and 40 DAS & $5.2(26.1)$ & $4.8(22.1)$ & $2.9(7.4)$ & $2.9(7.4)$ \\
\hline W5-Weedy check & $5.5(29.2)$ & $6.6(42.5)$ & $4.0(15.0)$ & $3.3(9.8)$ \\
\hline $\mathrm{SEm} \pm$ & 0.3 & 0.4 & 0.1 & 0.2 \\
\hline $\mathrm{CD}(\mathrm{P}=0.05)$ & 1.0 & 1.2 & 0.3 & 0.5 \\
\hline
\end{tabular}

*Original values within parentheses and $\sqrt{x+1}$ transformed values outside parentheses

$\mathrm{Mz}$ - Maize, $\mathrm{Rb}$ - Runner bean, DAS- Days after sowing, MW- manual weeding

\section{Total weed density}

Among planting patterns, $100 \%$ maize $+100 \%$ runner bean in the same row recorded the minimum weed density and all other planting patterns proved inferior in reducing weed density. In subsequent stages, sole runner bean was equally effective in reducing weed density (Table 5.).

Among weed management practices, pendimethalin $1.0 \mathrm{~kg} / \mathrm{ha}$ + one manual weeding and pendimethalin $1.0 \mathrm{~kg} / \mathrm{ha}$ alone and metribuzine $0.03 \mathrm{~kg} / \mathrm{ha}$ alone proved superior to hoeing and weeding twice and weedy check at 15 DAS. At subsequent stages, all the four weed management practices proved superior to weedy check, but pendimethalin $1.0 \mathrm{~kg} / \mathrm{ha}+$ one manual weeding, recorded the least total weed density. At 45 DAS, bot pendimethalin $1.0 \mathrm{~kg} / \mathrm{ha}+$ manual weeding and pendimethalin $1.0 \mathrm{~kg} / \mathrm{ha}$ alone were statistically at par with for this parameter.

\section{Total weed dry weight}

Among planting patterns, $100 \%$ maize $+100 \%$ runner bean in the same row recorded the minimum dry weight of weeds at all the stages. At all stages, all intercropping systems and sole runner bean recorded significantly less weed dry weight than sole maize (Table 6.).

Among weed management practices, pendimethalin $1.0 \mathrm{~kg} / \mathrm{ha}$ + manual weeding, pendimethalin $1.0 \mathrm{~kg} / \mathrm{ha}$ alone recorded significantly less weed dry weight than weedy check and hoeing and weeding at 21 and 40 DAS. At subsequent stages, all weed management practices recorded significantly less dry weight of weeds than weedy check.

At 45 DAS, hoeing and weeding at 21 and 40 DAS recorded the minimum dry weight of weeds and pendimethalin 1.0 $\mathrm{kg} / \mathrm{ha}+$ one manual weeding and pendimethalin $1.0 \mathrm{~kg} / \mathrm{ha}$ alone remained at par with it. At 75 DAS and harvest, pendimethalin $1.0 \mathrm{~kg} / \mathrm{ha}+$ one manual weeding and pendimethalin $1.0 \mathrm{~kg} / \mathrm{ha}$ alone remained at par with it. At 75 DAS and harvest, pendimethalin $1.0 \mathrm{~kg} / \mathrm{ha}+$ one manual weeding proved the best with the minimum dry weight of weeds and all weed management practices proved significantly inferior in reducing dry weight of weeds.

Table 5: Total weed density $\left(\right.$ per $\mathrm{m}^{2}$ ) as influenced by various treatments

\begin{tabular}{|c|c|c|c|c|}
\hline Treatment & 15 DAS & 45 DAS & 75 DAS & Harvest \\
\hline \multicolumn{5}{|c|}{ Planting pattern } \\
\hline $\mathrm{P}_{1}$-Sole Mz & $12.2(147.8)$ & $7.2(50.8)$ & $6.1(36.2)$ & $7.9(61.4)$ \\
\hline $\mathrm{P}_{2}$-Sole $\mathrm{Rb}$ & $12.1(145.4)$ & $5.8(32.6)$ & $4.3(17.5)$ & $3.4(10.5)$ \\
\hline $\mathrm{P}_{3}-\mathrm{Mz} 100 \%+\mathrm{Rb} 100 \%(2: 2)$ in separate rows & $13.7(186.6)$ & $8.4(69.5)$ & $6.8(45.2)$ & $6.4(39.9)$ \\
\hline $\mathrm{P}_{4}-\mathrm{Mz} 100 \%+\mathrm{Rb} 100 \%$ in the same row & $10.3(105.1)$ & $6.1(36.2)$ & $6.1(36.2)$ & $4.3(17.5)$ \\
\hline $\mathrm{P}_{5}-\mathrm{Mz} 100 \%+\mathrm{Rb} 50 \%$ (2:1) in separate rows & $13.4(178.5)$ & $9.3(85.5)$ & $8.1(64.6)$ & $7.2(50.8)$ \\
\hline $\mathrm{P}_{6}-\mathrm{Mz} 100 \%+\mathrm{Rb} 50 \%$ in the same row & $8.8(76.4)$ & $6.5(41.2)$ & $3.9(14.2)$ & $4.9(23.1)$ \\
\hline SEm \pm & 0.6 & 0.6 & 0.1 & 0.1 \\
\hline $\mathrm{CD}(\mathrm{P}=0.05)$ & 2.4 & 2.2 & 0.5 & 0.5 \\
\hline \multicolumn{5}{|c|}{ Weed management } \\
\hline $\mathrm{W}_{1}$-Pendimethalin $1.0 \mathrm{~kg} / \mathrm{ha}$ & $8.1(64.6)$ & $5.5(29.2)$ & $4.5(19.2)$ & $4.1(15.8)$ \\
\hline $\mathrm{W}_{2}$-Metribuzin $0.03 \mathrm{~kg} / \mathrm{ha}$ & $8.3(67.8)$ & $7.7(58.2)$ & $7.1(49.4)$ & $7.4(53.7)$ \\
\hline $\mathrm{W}_{3}$-Pendimethalin $1.0 \mathrm{~kg} / \mathrm{ha}+1 \mathrm{MW}$ at $25 \mathrm{DAS}$ & $6.4(39.9)$ & $5.3(29.1)$ & $3.5(11.2)$ & $1.8(2.2)$ \\
\hline $\mathrm{W}_{4-}$ Hoeing and weeding at 21 and 40 DAS & $18.3(333.8)$ & $6.3(38.6)$ & $5.2(26.1)$ & $6.8(45.2)$ \\
\hline $\mathrm{W}_{5}$-Weedy check & 18.7 (348.6) & $15.3(233.1)$ & $10.1(101.1)$ & $8.6(72.9)$ \\
\hline $\mathrm{SEm} \pm$ & 0.4 & 0.4 & 0.1 & 0.2 \\
\hline $\mathrm{CD}(\mathrm{P}=0.05)$ & 1.4 & 1.2 & 0.4 & 0.6 \\
\hline
\end{tabular}

*Original values within parentheses and $\sqrt{x+1}$ transformed values outside parentheses

$\mathrm{Mz}$ - Maize, $\mathrm{Rb}$ - Runner bean, DAS- Days after sowing, MW- manual weeding 
Table 6: Total weed dry weight $\left(\mathrm{g} / \mathrm{m}^{2}\right)$ as influenced by various treatments

\begin{tabular}{|c|c|c|c|c|}
\hline Treatment & 15 DAS & 45 DAS & 75 DAS & Harvest \\
\hline \multicolumn{5}{|c|}{ Planting pattern } \\
\hline $\mathrm{P}_{1}-$ Sole $\mathrm{Mz}$ & $5.8(32.6)$ & $12.3(56.7)$ & $19.5(379.2)$ & $18.2(330.2)$ \\
\hline $\mathrm{P}_{2}$-Sole $\mathrm{Rb}$ & $4.2(16.6)$ & $6.3(38.6)$ & $10.1(101.0)$ & $11.9(140.6)$ \\
\hline $\mathrm{P}_{3}-\mathrm{Mz} 100 \%+\mathrm{Rb} 100 \%(2: 2)$ in separate rows & $4.8(22.1)$ & $6.8(45.2)$ & $16.1(258.2)$ & $14.1(197.8)$ \\
\hline $\mathrm{P}_{4}-\mathrm{Mz} 100 \%+\mathrm{Rb} 100 \%$ in the same row & $2.8(6.8)$ & $6.2(46.6)$ & $9.5(89.2)$ & $7.8(59.8))$ \\
\hline $\mathrm{P}_{5}-\mathrm{Mz} 100 \%+\mathrm{Rb} 50 \%$ (2:1) in separate rows & $5.5(29.2)$ & $9.1(81.8)$ & $11.5(131.2)$ & $17.9(319.4)$ \\
\hline $\mathrm{P}_{6}-\mathrm{Mz} 100 \%+\mathrm{Rb} 50 \%$ in the same row & $3.7(12.6)$ & $7.8(95.1)$ & $11.3(126.6)$ & $9.1(81.8)$ \\
\hline $\mathrm{SEm} \pm$ & 0.1 & 0.7 & 0.3 & 0.2 \\
\hline $\mathrm{CD}(\mathrm{P}=0.05)$ & 0.5 & 2.5 & 1.2 & 0.9 \\
\hline \multicolumn{5}{|c|}{ Weed management } \\
\hline $\mathrm{W}_{1}$-Pendimethalin $1.0 \mathrm{~kg} / \mathrm{ha}$ & $2.5(5.2)$ & $4.9(23.1)$ & $10.7(113.4)$ & $12.2(147.8)$ \\
\hline $\mathrm{W}_{2}$-Metribuzin $0.03 \mathrm{~kg} / \mathrm{ha}$ & $2.9(7.4)$ & $6.6(42.5)$ & $13.6(183.9)$ & $16.4(267.9)$ \\
\hline $\mathrm{W}_{3}$-Pendimethalin $1.0 \mathrm{~kg} / \mathrm{ha}+1 \mathrm{MW}$ at $25 \mathrm{DAS}$ & $2.2(3.8)$ & $4.3(17.5)$ & $9.8(95.1)$ & $7.5(55.2)$ \\
\hline $\mathrm{W}_{4}$ - Hoeing and weeding at 21 and 40 DAS & $7.2(50.8)$ & $4.1(15.8)$ & $11.1(122.2)$ & $16.3(264.6)$ \\
\hline $\mathrm{W}_{5}$-Weedy check & $7.5(55.2)$ & $21.2(448.4)$ & $22.5(505.2)$ & $17.9(319.4)$ \\
\hline $\mathrm{SEm} \pm$ & 0.1 & 0.4 & 0.3 & 0.3 \\
\hline $\mathrm{CD}(\mathrm{P}=0.05)$ & 0.3 & 1.4 & 0.8 & 1.0 \\
\hline
\end{tabular}

*Original values within parentheses and $\sqrt{x+1}$ transformed values outside parentheses

$\mathrm{Mz}$ - Maize, Rb - Runner bean, DAS- Days after sowing, MW- manual weeding

\section{Weed control efficiency}

At 15 DAS, treatments involving herbicides recorded higher weed control efficiency (WCE) values and pendimethalin 1.0 $\mathrm{kg} / \mathrm{ha}+$ manual weeding and pendimethalin $1.0 \mathrm{~kg} / \mathrm{ha}$ alone recorded WCE values of 90.5 and $93.1 \%$ respectively. At 45 DAS, all weed management practices were highly efficient in controlling weeds and the WCE values were above $90 \%$. At $75 \mathrm{DAS}$, pendimethalin $1.0 \mathrm{~kg} / \mathrm{ha}$ + one manual weeding recorded the maximum value of $81.2 \%$. At harvest, pendimethalin $1.0 \mathrm{~kg} / \mathrm{ha}$ + one manual weeding recorded the maximum WCE of $82.5 \%$. Excepting pendimethalin 1.0 $\mathrm{kg} / \mathrm{ha}+$ one manual weeding, all other weed management practices showed loss in WCE values at harvest. The WCE values of $94.5,90.5$ and $96.5 \%$ with pendimethalin $1.0 \mathrm{~kg} / \mathrm{ha}$ alone, metribuzine $0.03 \mathrm{~kg} / \mathrm{ha}$ alone and hoeing and weeding at 21 and 40 DAS, respectively at 45 DAS declined to 53.8, 15.8 and $17.2 \%$ at harvest (Table 7.)

\section{Weed smothering efficiency}

Among the planting patterns, $100 \%$ maize $+100 \%$ runnerbean in the same row recorded the maximum weed smothering efficiency (WSE) value of $81.3 \%$, whereas, the same planting pattern in separate rows proved the least efficient and recorded the minimum WSE value of $3.9 \%$. Maize $100 \%$ + runner bean $100 \%$ separate rows were moderately efficient in smothering the weeds with WSE value of $40.2 \%$ (Table 8 .).

Table 7: Weed control efficiency (\%) as influenced by various weed management practices

\begin{tabular}{|c|c|c|c|c|}
\hline Weed management & 15 DAS 45 DAS & 75 DAS Harvest \\
\hline $\mathrm{W}_{1}$-Pendimethalin 1.0 kg /ha & 92.4 & 94.5 & 77.5 & 53.8 \\
\hline $\mathrm{W}_{2}$-Metribuzin 0.03 kg /ha & 86.6 & 90.5 & 63.6 & 15.8 \\
\hline $\mathrm{W}_{3}$-Pendimethalin 1.0 kg/ha + 1 MW at 25 DAS & 91.5 & 96.1 & 81.2 & 82.5 \\
\hline $\mathrm{W}_{4}$ - Hoeing and weeding at 21 and 40 DAS & 7.97 & 96.5 & 75.8 & 17.2 \\
\hline $\mathrm{W}_{5}$-Weedy check & - & - & - & - \\
\hline
\end{tabular}

*Data not statistically analyzed

DAS- days after sowing, MW- manual weeding

Table 8: Weed smothering efficiency (\%) at harvest

\begin{tabular}{|c|c|}
\hline Planting pattern & WSE (\%) \\
\hline $\mathrm{P}_{1}$-Sole $\mathrm{Mz}$ & - \\
\hline $\mathrm{P}_{2}$-Sole $\mathrm{Rb}$ & - \\
\hline $\mathrm{P}_{3}-\mathrm{Mz} 100 \%+\mathrm{Rb} 100 \%(2: 2)$ in separate rows & 40.2 \\
\hline $\mathrm{P}_{4}-\mathrm{Mz} 100 \%+\mathrm{Rb} 100 \%$ in the same row & 81.3 \\
\hline $\mathrm{P}_{5}-\mathrm{Mz} 100 \%+\mathrm{Rb} 50 \%$ (2:1) in separate rows & 3.9 \\
\hline $\mathrm{P}_{6}-\mathrm{Mz} 100 \%+\mathrm{Rb} 50 \%$ in the same row & 75.2 \\
\hline
\end{tabular}

*Data not statistically analyzed

\section{Nutrient studies}

\section{Nutrient content in maize}

The nitrogen, phosphorous and potassium content varied between $1.18-1.61 \%, 0.26-0.50 \%$ and $0.29-0.37 \%$ due to planting patterns. The minimum NPK content in grain was recorded with maize $100 \%$ + runner bean $100 \%$ in same row and the maximum values were obtained in maize $100 \%+$ runner bean $50 \%$ in separate rows (Table 9.)
The N, P and $\mathrm{K}$ content of maize grain varied between 1.15$1.56 \%, 0.35-0.48$ and $0.300 .35 \%$ due to weed management practices. The minimum $\mathrm{N}$ and $\mathrm{K}$ contents were recorded in weedy check and the maximum values were obtained in pendimethalin $1.0 \mathrm{~kg} / \mathrm{ha}+$ one manual weeding.

The N, P and $\mathrm{K}$ content in maize stover varied between 0.49 $0.67 \%, 0.20-0.23 \%$ and $1.41-1.82 \%$, respectively due to various planting patterns. The minimum values were recorded in maize $100 \%$ + runner bean $100 \%$ in same row and the 
maximum values were obtained in maize $100 \%$ + runner bean $50 \%$ in separate rows.

The N, P and K content in maize stover ranged between 0.48 $0.65 \%, 0.20-0.24 \%$ and $1.46-1.71 \%$ due to weed management practices. The minimum values were recorded with weedy check and the maximum values were recorded with pendimethalin + one manual weeding or pendimethalin $1.0 \mathrm{~kg} / \mathrm{ha}$ alone.

\section{Nutrient uptake in maize}

Among the planting patterns, sole maize recorded the maximum uptake of 80.10, 22.62 and $18.82 \mathrm{~kg} / \mathrm{ha} \mathrm{N}, \mathrm{P}$ and $\mathrm{K}$ by the grain. Weed management practices influenced nutrient uptake significantly. The N, P and K uptake by grain under pendimethalin + one manual weeding were 84.13, 21.15 and $19.03 \mathrm{~kg} / \mathrm{ha}$ (Table 10.).

The uptake of N, P and K by stover was 46.72, 17.56 and $126.15 \mathrm{~kg} / \mathrm{ha}$ respectively in sole maize and the total nutrient uptake by the crop amounts to $126.82,40.21$ and 144.67 $\mathrm{kg} / \mathrm{ha}$. Pendimethalin $1.0 \mathrm{~kg} / \mathrm{ha}+$ one manual weeding facilitated maximum N, P and K uptake of 51.12, 19.27 and $134.57 \mathrm{~kg} / \mathrm{ha}$ respectively by stover. The minimum uptake values were recorded in case of weedy check.

The N, P and K uptake by crop (grain + stover) amounts to $135.25,40.42$ and $153.60 \mathrm{~kg} / \mathrm{ha}$ under integrated weed management practice comprising pre- emergent application of pendimethalin $1.0 \mathrm{~kg} / \mathrm{ha}$ followed by one manual weeding at 25 DAS.

\section{Nutrient content in runner bean}

The N, P and $\mathrm{K}$ content in the pods of runner bean ranged between 3.59 - 4.03, 0.24- 0.52 and $1.86-2.04 \%$ respectively. The maximum $\mathrm{N}$ and $\mathrm{P}$ content were recorded with pods of sole runner bean.

However, the maximum $\mathrm{K}$ content was recorded in maize $100 \%$ + runner bean $100 \%$ in the same row.

The N, P and K content of the pod ranged from 3.70- 3.91, $0.33-0.48$ and $1.91-2.02 \%$ due to weed management practices. The minimum $\mathrm{N}, \mathrm{P}$ and $\mathrm{K}$ content of the pod was recorded in weedy check and the maximum in pendimethalin $1.0 \mathrm{~kg} / \mathrm{ha}+$ one manual weeding.

The $\mathrm{N}, \mathrm{P}$, and $\mathrm{K}$ content in haulm ranged between 1.05- 1.18, $0.12-0.26$ and $1.17-1.28 \%$ respectively under various planting patterns. The minimum $\mathrm{N}, \mathrm{P}$ and $\mathrm{K}$ content was recorded in maize $100 \%$ + runner bean $50 \%$ in separate rows. The $\mathrm{N}, \mathrm{P}$ and $\mathrm{K}$ content of runner bean haulm ranged between $1.08-1.15,0.16-0.23$ and $1.20-1.26 \%$ respectively under various weed management. The minimum N, P and $\mathrm{K}$ content in the haulm was recorded in weedy check and maximum values were obtained in pendimethalin $1.0 \mathrm{~kg} / \mathrm{ha}+$ one manual weeding (Table 11.).

\section{Nutrient uptake in runner bean}

Among the planting patterns, sole runner bean recorded the maximum uptake of $4.03,0.5$ and $2.02 \mathrm{~kg} / \mathrm{ha} \mathrm{N}, \mathrm{P}$ and $\mathrm{K}$ by the pod. Weed management practices influenced nutrient uptake significantly. The $\mathrm{N}, \mathrm{P}$ and $\mathrm{K}$ uptake by grain under pendimethalin + one manual weeding were $3.91,0.47$ and $2.02 \mathrm{~kg} / \mathrm{ha}$ (Table 12.).

The uptake of N, P and K by haulm was 42.85, 5.79 and 22.44 $\mathrm{kg} / \mathrm{ha}$ respectively. The total nutrient uptake by the crop amounts to $66.64,8.76$ and $33.45 \mathrm{~kg} / \mathrm{ha}$. Pendimethalin 1.0 $\mathrm{kg} / \mathrm{ha}+$ one manual weeding facilitated maximum $\mathrm{N}, \mathrm{P}$ and $\mathrm{K}$ uptake of $60.45,7.72$ and $30.95 \mathrm{~kg} / \mathrm{ha}$ respectively by the haulm. The minimum uptake values were recorded in case of weedy check.

The N, P and K uptake by crop (pod + haulm) amounts to 64.36, 8.19 and $32.97 \mathrm{~kg} / \mathrm{ha}$ under integrated weed management practice comprising pre- emergent application of pendimethalin $1.0 \mathrm{~kg} / \mathrm{ha}$ followed by one manual weeding at 25 DAS.

\section{Nutrient content and uptake by weeds}

The N, P and $\mathrm{K}$ content of weeds due to planting patterns varied between 1.58- $1.81,0.56-1.21$ and $1.57-2.30 \%$ respectively. Weeds under sole maize had maximum value of nutrient content and took the maximum of 56.85, 39.95 and $75.94 \mathrm{~kg} / \mathrm{ha}$ of $\mathrm{N}, \mathrm{P}$ and $\mathrm{K}$ respectively. Nutrient uptake by weeds was less under intercropping systems as compared to sole maize (Table 14.).

The N, $\mathrm{P}$ and $\mathrm{K}$ content varied between 1.55- 1.78, 0.80- 0.92 and $1.77-1.95 \%$ respectively due to weed management practices. The nutrient content of weeds was maximum under weedy check. The weeds took maximum N, P and K of 56.85, 29.38 and $62.28 \mathrm{~kg} / \mathrm{ha}$.

Table 9: Nutrient content (\%) in maize stover and grain at harvest as influenced by various treatments

\begin{tabular}{|c|c|c|c|c|c|c|}
\hline \multirow{2}{*}{ Treatment } & \multicolumn{3}{|c|}{ Grain } & \multicolumn{3}{|c|}{ Stover } \\
\hline & $\mathbf{N}$ & $\mathbf{P}$ & $\mathbf{K}$ & $\mathbf{N}$ & $\mathbf{P}$ & $\mathbf{K}$ \\
\hline \multicolumn{7}{|c|}{ Planting pattern } \\
\hline $\mathrm{P}_{1-S o l e ~} \mathrm{Mz}$ & 1.51 & 0.43 & 0.35 & 0.63 & 0.23 & 1.71 \\
\hline $\mathrm{P}_{3}-\mathrm{Mz} 100 \%+\mathrm{Rb} 100 \%(2: 2)$ in separate rows & 1.40 & 0.39 & 0.35 & 0.58 & 0.22 & 1.70 \\
\hline $\mathrm{P}_{4}-\mathrm{Mz} 100 \%+\mathrm{Rb} 100 \%$ in the same row & 1.18 & 0.26 & 0.29 & 0.49 & 0.20 & 1.41 \\
\hline $\mathrm{P}_{5}-\mathrm{Mz} 100 \%+\mathrm{Rb} 50 \%$ (2:1) in separate rows & 1.61 & 0.44 & 0.37 & 0.67 & 0.23 & 1.82 \\
\hline $\mathrm{P}_{6}-\mathrm{Mz} 100 \%+\mathrm{Rb} 50 \%$ in the same row & 1.33 & 0.50 & 0.31 & 0.55 & 0.22 & 1.54 \\
\hline $\mathrm{SEm} \pm$ & 0.04 & 0.01 & 0.02 & 0.01 & 0.01 & 0.02 \\
\hline $\mathrm{CD}(\mathrm{P}=0.05)$ & 0.15 & 0.04 & 0.07 & 0.06 & 0.01 & 0.08 \\
\hline \multicolumn{7}{|c|}{ Weed management } \\
\hline $\mathrm{W}_{1}$-Pendimethalin $1.0 \mathrm{~kg} / \mathrm{ha}$ & 1.54 & 0.40 & 0.35 & 0.64 & 0.24 & 1.71 \\
\hline $\mathrm{W}_{2}$-Metribuzin $0.03 \mathrm{~kg} / \mathrm{ha}$ & 1.43 & 0.39 & 0.34 & 0.60 & 0.22 & 1.67 \\
\hline $\mathrm{W}_{3}$-Pendimethalin $1.0 \mathrm{~kg} / \mathrm{ha}+1 \mathrm{MW}$ at $25 \mathrm{DAS}$ & 1.56 & 0.39 & 0.35 & 0.65 & 0.24 & 1.70 \\
\hline $\mathrm{W}_{4-}$ Hoeing and weeding at 21 and 40 DAS & 1.34 & 0.35 & 0.33 & 0.56 & 0.21 & 1.62 \\
\hline $\mathrm{W}_{5}$-Weedy check & 1.15 & 0.48 & 0.30 & 0.48 & 0.20 & 1.46 \\
\hline $\mathrm{SEm} \pm$ & 0.02 & 0.01 & 0.01 & 0.01 & 0.02 & 0.01 \\
\hline $\mathrm{CD}(\mathrm{P}=0.05)$ & 0.03 & 0.01 & 0.04 & 0.07 & 0.02 & 0.01 \\
\hline
\end{tabular}

* Mz - Maize, $\mathrm{Rb}$ - Runner bean, DAS- Days after sowing, MW- manual weeding 
Table 10: Nutrient uptake $(\mathrm{kg} / \mathrm{ha})$ in maize stover and grain at harvest as influenced by various treatments

\begin{tabular}{|c|c|c|c|c|c|c|}
\hline \multirow{2}{*}{ Treatment } & \multicolumn{3}{|c|}{ Grain } & \multicolumn{3}{|c|}{ Stover } \\
\hline & $\mathbf{N}$ & $\mathbf{P}$ & $\mathbf{K}$ & $\mathbf{N}$ & $\mathbf{P}$ & $\mathbf{K}$ \\
\hline \multicolumn{7}{|c|}{ Planting pattern } \\
\hline $\mathrm{P}_{1-S o l e ~} \mathrm{Mz}$ & 80.10 & 22.62 & 18.52 & 46.72 & 17.59 & 126.15 \\
\hline $\mathrm{P}_{3}-\mathrm{Mz} 100 \%+\mathrm{Rb} 100 \%(2: 2)$ in separate rows & 61.22 & 16.86 & 15.12 & 60.01 & 23.01 & 172.24 \\
\hline $\mathrm{P}_{4}-\mathrm{Mz} 100 \%+\mathrm{Rb} 100 \%$ in the same row & 39.33 & 8.90 & 9.63 & 44.63 & 18.71 & 126.97 \\
\hline $\mathrm{P}_{5}-\mathrm{Mz} 100 \%+\mathrm{Rb} 50 \%$ (2:1) in separate rows & 78.32 & 21.29 & 18.28 & 33.09 & 11.66 & 89.34 \\
\hline $\mathrm{P}_{6}-\mathrm{Mz} 100 \%+\mathrm{Rb} 50 \%$ in the same row & 59.13 & 19.68 & 14.02 & 24.23 & 9.52 & 66.72 \\
\hline $\mathrm{SEm} \pm$ & 2.37 & 0.78 & 0.35 & 1.80 & 0.27 & 2.21 \\
\hline $\mathrm{CD}(\mathrm{P}=0.05)$ & 8.63 & 2.86 & 1.29 & 6.55 & 0.99 & 8.04 \\
\hline \multicolumn{7}{|c|}{ Weed management } \\
\hline $\mathrm{W}_{1}$-Pendimethalin $1.0 \mathrm{~kg} / \mathrm{ha}$ & 83.50 & 21.89 & 19.12 & 48.69 & 18.39 & 130.66 \\
\hline $\mathrm{W}_{2}$-Metribuzin $0.03 \mathrm{~kg} / \mathrm{ha}$ & 63.95 & 17.67 & 15.32 & 43.73 & 16.73 & 121.86 \\
\hline $\mathrm{W}_{3}$-Pendimethalin $1.0 \mathrm{~kg} / \mathrm{ha}+1 \mathrm{MW}$ at $25 \mathrm{DAS}$ & 84.13 & 21.15 & 19.03 & 51.12 & 19.27 & 134.57 \\
\hline $\mathrm{W}_{4-}$ Hoeing and weeding at 21 and $40 \mathrm{DAS}$ & 54.64 & 14.64 & 13.6 & 35.31 & 13.49 & 102.89 \\
\hline $\mathrm{W}_{5}$-Weedy check & 31.88 & 14.00 & 8.45 & 29.83 & 12.60 & 91.44 \\
\hline $\mathrm{SEm} \pm$ & 1.43 & \begin{tabular}{|l|}
0.51 \\
\end{tabular} & 0.33 & \begin{tabular}{|l|}
1.33 \\
\end{tabular} & \begin{tabular}{|l|}
0.45 \\
\end{tabular} & 2.93 \\
\hline $\mathrm{CD}(\mathrm{P}=0.05)$ & 4.17 & 1.49 & 0.96 & 3.90 & 1.33 & 8.75 \\
\hline
\end{tabular}

${ }^{*} \mathrm{Mz}$ - Maize, $\mathrm{Rb}$ - Runner bean, DAS- Days after sowing, MW- manual weeding

Table 11: Nutrient content (\%) in runner bean pod and haulm at harvest as influenced by various treatments

\begin{tabular}{|c|c|c|c|c|c|c|}
\hline \multirow{2}{*}{ Treatment } & \multicolumn{3}{|c|}{ Pod } & \multicolumn{3}{|c|}{ Haulm } \\
\hline & $\mathbf{N}$ & $\mathbf{P}$ & $\mathbf{K}$ & $\mathbf{N}$ & $\mathbf{P}$ & $\mathbf{K}$ \\
\hline \multicolumn{7}{|c|}{ Planting pattern } \\
\hline $\mathrm{P}_{2}$-Sole $\mathrm{Rb}$ & 4.03 & 0.52 & 2.02 & 1.18 & 0.26 & 1.26 \\
\hline $\mathrm{P}_{3}-\mathrm{Mz} 100 \%+\mathrm{Rb} 100 \%(2: 2)$ in separate rows & 3.75 & 0.42 & 1.99 & 1.07 & 0.21 & 1.24 \\
\hline $\mathrm{P}_{4}-\mathrm{Mz} 100 \%+\mathrm{Rb} 100 \%$ in the same row & 3.94 & 0.51 & 2.04 & 1.16 & 0.25 & 1.28 \\
\hline $\mathrm{P}_{5}-\mathrm{Mz} 100 \%+\mathrm{Rb} 50 \%$ (2:1) in separate rows & 3.59 & 0.24 & 1.86 & 1.05 & 0.12 & 1.17 \\
\hline $\mathrm{P}_{6-\mathrm{Mz}} 100 \%+\mathrm{Rb} 50 \%$ in the same row & 3.68 & 0.35 & 1.93 & 1.08 & 0.17 & 1.21 \\
\hline SEm & 0.01 & 0.05 & 0.06 & 0.01 & 0.01 & 0.01 \\
\hline $\mathrm{CD}(\mathrm{P}=0.05)$ & 0.03 & 0.05 & 0.06 & 0.02 & 0.02 & 0.04 \\
\hline \multicolumn{7}{|l|}{ Weed managen } \\
\hline $\mathrm{W}_{1}$-Pendimethalin $1.0 \mathrm{~kg} / \mathrm{ha}$ & 3.81 & 0.45 & 2.00 & 1.12 & 0.22 & 1.25 \\
\hline $\mathrm{W}_{2}$-Metribuzin $0.03 \mathrm{~kg} / \mathrm{ha}$ & 3.83 & 0.40 & 1.96 & 1.13 & 0.20 & 1.23 \\
\hline $\mathrm{W}_{3}$-Pendimethalin $1.0 \mathrm{~kg} / \mathrm{ha}+1 \mathrm{MW}$ at $25 \mathrm{DAS}$ & 3.91 & 0.47 & 2.02 & 1.15 & 0.23 & 1.26 \\
\hline $\mathrm{W}_{4}$ - Hoeing and weeding at 21 and 40 DAS & 3.73 & 0.38 & 1.96 & 1.10 & 0.19 & 1.22 \\
\hline $\mathrm{W}_{5}$-Weedy check & 3.70 & 0.33 & 1.91 & 1.08 & 0.16 & 1.20 \\
\hline SEm & 0.01 & 0.01 & 0.01 & 0.01 & 0.02 & 0.01 \\
\hline $\mathrm{CD}(\mathrm{P}=0.05)$ & 0.05 & 0.02 & 0.03 & 0.01 & 0.02 & 0.02 \\
\hline
\end{tabular}

$* \mathrm{Mz}-$ Maize, $\mathrm{Rb}-$ Runner bean, DAS- Days after sowing, MW- manual weeding

Table 12: Nutrient uptake (kg/ha) by runner bean pod and haulm at harvest as influenced by various treatments

\begin{tabular}{|c|c|c|c|c|c|c|}
\hline \multirow{2}{*}{ Treatment } & \multicolumn{3}{|c|}{ Pod } & \multicolumn{3}{|c|}{ Haulm } \\
\hline & $\mathbf{N}$ & $\mathbf{P}$ & $\mathbf{K}$ & $\mathbf{N}$ & $\mathbf{P}$ & $\mathbf{K}$ \\
\hline \multicolumn{7}{|c|}{ Planting pattern } \\
\hline $\mathrm{P}_{2}$-Sole $\mathrm{Rb}$ & 62.61 & 8.24 & 31.43 & 4.03 & 0.52 & 2.02 \\
\hline $\mathrm{P}_{3}-\mathrm{Mz} 100 \%+\mathrm{Rb} 100 \%(2: 2)$ in separate rows & 33.73 & 3.92 & 17.91 & 3.75 & 0.42 & 1.99 \\
\hline $\mathrm{P}_{4}-\mathrm{Mz} 100 \%+\mathrm{Rb} 100 \%$ in the same row & 48.89 & 6.65 & 25.28 & 3.94 & 0.51 & 2.04 \\
\hline $\mathrm{P}_{5}-\mathrm{Mz} 100 \%+\mathrm{Rb} 50 \%$ (2:1) in separate rows & 13.30 & 0.95 & 6.94 & 3.59 & 0.24 & 1.86 \\
\hline $\mathrm{P}_{6}-\mathrm{Mz} 100 \%+\mathrm{Rb} 50 \%$ in the same row & 22.38 & 2.20 & 11.71 & 3.68 & 0.35 & 1.93 \\
\hline SEm \pm & 0.83 & 0.16 & 0.41 & 0.02 & 0.01 & 0.01 \\
\hline $\mathrm{CD}(\mathrm{P}=0.05)$ & 3.02 & 0.59 & 1.50 & 0.03 & 0.05 & 0.06 \\
\hline $\mathrm{W}_{1}$-Pendimethalin $1.0 \mathrm{~kg} / \mathrm{ha}$ & 42.85 & 5.79 & 22.44 & 3.81 & 0.45 & 2.00 \\
\hline $\mathrm{W}_{2}$-Metribuzin $0.03 \mathrm{~kg} / \mathrm{ha}$ & 30.94 & 3.55 & 15.63 & 3.83 & 0.40 & 1.96 \\
\hline $\mathrm{W}_{3}$-Pendimethalin $1.0 \mathrm{~kg} / \mathrm{ha}+1 \mathrm{MW}$ at $25 \mathrm{DAS}$ & 60.45 & 7.72 & 30.95 & 3.91 & 0.47 & 2.02 \\
\hline $\mathrm{W}_{4-}$ Hoeing and weeding at 21 and 40 DAS & 29.19 & 3.25 & 15.24 & 3.73 & 0.38 & 1.96 \\
\hline $\mathrm{W}_{5}$-Weedy check & 17.48 & 1.66 & 9.01 & 3.71 & 0.33 & 1.91 \\
\hline $\mathrm{SEm} \pm$ & 1.88 & 0.18 & 0.96 & \begin{tabular}{|l|}
0.01 \\
\end{tabular} & 0.008 & 0.01 \\
\hline $\mathrm{CD}(\mathrm{P}=0.05)$ & 5.51 & 0.53 & 2.814 & 0.05 & \begin{tabular}{|l|}
0.02 \\
\end{tabular} & 0.03 \\
\hline
\end{tabular}

*Mz - Maize, $\mathrm{Rb}$ - Runner bean, DAS- Days after sowing, MW- manual weeding 
Table 13: Nutrient uptake $(\mathrm{kg} / \mathrm{ha})$ by the system at harvest as influenced by various treatments

\begin{tabular}{|c|c|c|c|}
\hline Treatments & $\mathbf{N}$ (kg/ha) & P (kg/ha) & K (kg/ha) \\
\hline \multicolumn{4}{|l|}{ Planting pattern } \\
\hline $\mathrm{P}_{1}$-Sole Mz & 126.82 & 40.22 & 144.67 \\
\hline $\mathrm{P}_{2}$-Sole $\mathrm{Rb}$ & 149.99 & 27.57 & 124.61 \\
\hline $\mathrm{P}_{3}-\mathrm{Mz} 100 \%+\mathrm{Rb} 100 \%$ in separate rows as a 2:2 combination & 266.89 & 59.52 & 311.28 \\
\hline $\mathrm{P}_{4-} \mathrm{Mz} 100 \%+\mathrm{Rb} 100 \%$ in the same row & 237.26 & 47.70 & 276.92 \\
\hline $\mathrm{P}_{5}-\mathrm{Mz} 100 \%+\mathrm{Rb} 50 \%$ in separate rows as a $2: 1$ combination & 176.18 & 49.63 & 171.89 \\
\hline $\mathrm{P}_{6-} \mathrm{Mz} 100 \%+\mathrm{Rb} 50 \%$ in the same row & 152.51 & 49.23 & 144.62 \\
\hline SEm & 4.84 & 1.84 & 3.49 \\
\hline $\mathrm{CD}(\mathrm{P}=0.05)$ & 17.60 & 6.70 & 12.69 \\
\hline \multicolumn{4}{|l|}{ Weed management } \\
\hline $\mathrm{W}_{1}$-Pendimethalin $1.0 \mathrm{~kg} / \mathrm{ha}$ & 218.17 & 55.04 & 224.16 \\
\hline $\mathrm{W}_{2}$-Metribuzin $0.03 \mathrm{~kg} / \mathrm{ha}$ & 184.98 & 44.62 & 203.11 \\
\hline $\mathrm{W}_{3}$-Pendimethalin $1.0 \mathrm{~kg} / \mathrm{ha}+1 \mathrm{MW}$ at $25 \mathrm{DAS}$ & 239.65 & 56.58 & 237.80 \\
\hline $\mathrm{W}_{4-}$ Hoeing and weeding at 21 and 40 DAS & 158.54 & 37.66 & 175.73 \\
\hline $\mathrm{W}_{5}$-Weedy check & 123.35 & 34.32 & 154.19 \\
\hline SEm & 3.71 & 0.82 & 4.37 \\
\hline $\mathrm{CD}(\mathrm{P}=0.05)$ & 10.84 & 2.41 & 12.76 \\
\hline
\end{tabular}

*Mz - Maize, $\mathrm{Rb}$ - Runner bean, DAS- Days after sowing, MW- manual weeding

Table 14: Nutrient content $(\%)$ and uptake $(\mathrm{kg} / \mathrm{ha})$ by weeds at harvest as influenced by various treatments

\begin{tabular}{|c|c|c|c|c|c|c|}
\hline \multirow{2}{*}{ Treatment } & \multicolumn{3}{|c|}{ Content $(\%)$} & \multicolumn{3}{|c|}{ Uptake (kg/ha) } \\
\hline & $\mathbf{N}$ & $\mathbf{P}$ & $\mathbf{K}$ & $\mathbf{N}$ & $\mathbf{P}$ & $\mathbf{K}$ \\
\hline \multicolumn{7}{|c|}{ Planting pattern } \\
\hline $\mathrm{P}_{1}$-Sole $\mathrm{Mz}$ & 1.81 & 1.21 & 2.30 & 56.85 & 39.95 & 75.94 \\
\hline $\mathrm{P}_{2}$-Sole $\mathrm{Rb}$ & 1.71 & 1.21 & 2.22 & 24.04 & 17.01 & 31.12 \\
\hline $\mathrm{P}_{3}-\mathrm{Mz} 100 \%+\mathrm{Rb} 100 \%(2: 2)$ in separate rows & 1.59 & 0.56 & 1.60 & 31.45 & 11.07 & 31.64 \\
\hline $\mathrm{P}_{4}-\mathrm{Mz} 100 \%+\mathrm{Rb} 100 \%$ in the same row & 1.58 & 0.59 & 1.57 & 9.44 & 3.52 & 9.38 \\
\hline $\mathrm{P}_{5}-\mathrm{Mz} 100 \%+\mathrm{Rb} 50 \%$ (2:1) in separate rows & 1.64 & 0.78 & 1.71 & 52.38 & 24.91 & 54.61 \\
\hline $\mathrm{P}_{6}-\mathrm{Mz} 100 \%+\mathrm{Rb} 50 \%$ in the same row & 1.66 & 0.69 & 1.65 & 13.57 & 5.64 & 13.49 \\
\hline $\mathrm{SEm} \pm$ & 0.01 & 0.01 & 0.05 & 0.13 & 0.03 & 0.06 \\
\hline $\mathrm{CD}(\mathrm{P}=0.05)$ & 0.03 & 0.05 & 0.18 & 0.48 & 0.13 & 0.23 \\
\hline \multicolumn{7}{|c|}{ Weed management } \\
\hline $\mathrm{W}_{1}$-Pendimethalin $1.0 \mathrm{~kg} / \mathrm{ha}$ & 1.60 & 0.82 & 1.79 & 23.64 & 27.07 & 26.45 \\
\hline $\mathrm{W}_{2}$-Metribuzin $0.03 \mathrm{~kg} / \mathrm{ha}$ & 1.64 & 0.83 & 1.82 & 43.93 & 25.58 & 48.75 \\
\hline $\mathrm{W}_{3}$-Pendimethalin $1.0 \mathrm{~kg} / \mathrm{ha}+1 \mathrm{MW}$ at $25 \mathrm{DAS}$ & 1.55 & 0.80 & 1.77 & 8.55 & 15.82 & 9.77 \\
\hline $\mathrm{W}_{4-}$ Hoeing and weeding at 21 and 40 DAS & 1.70 & 0.86 & 1.88 & 44.98 & 22.75 & 49.74 \\
\hline $\mathrm{W}_{5}$-Weedy check & 1.78 & 0.92 & 1.95 & 56.85 & 29.38 & 62.28 \\
\hline $\mathrm{SEm} \pm$ & 0.004 & 0.005 & 0.012 & 0.16 & 0.03 & 0.06 \\
\hline $\mathrm{CD}(\mathrm{P}=0.05)$ & 0.01 & 0.01 & 0.03 & 0.47 & 0.09 & 0.19 \\
\hline
\end{tabular}

\section{Discussion}

\section{Effect of treatments on weed dynamics of the system}

There were twelve weed species pre- dominantly found in the experimental field during the cropping season. It included the following five grasses i.e., Cynodon dactylon (L.) Pers., Dactyloctenium aegyptium (L.) Willd.., Digitaria sanguinalis L., Echinocloa colona (L.) Link., Eleusine indica (L.) Gaertn, one sedge specie, Cyperus rotundus L. and six broad leaved weed species that included Cleome rutidosperma DC., Cleome viscosa L., Commelina benghalensis L. Ipomoea pestigridis L., Melochia corchorifolia L. and Trianthema portulacastrum $\mathrm{L}$. This was in agreement with the weed flora as recorded by Behera et al. (1998) [1], Bhuvaneshwari et al. (2002) ${ }^{[2]}$, Uchino et al. (2008) ${ }^{[12]}$, Jamshidi (2013) ${ }^{[7]}$ and Sharma et al. (2013) ${ }^{[11]}$. It is interesting to note that the diversity among the grassy weed species at all stages is very less. However, it contributes majorly to the total weed density and dry weight due to their fast growing nature. This is opposite as in the case of broad leaved weeds. The density of sedges in the entire experimental plot was negligible and not significant during the various crop growth stages. This may have been due to the low mean temperature during the rabi season which did not favour the establishment of the sedges.
Among planting patterns, $100 \%$ maize $+100 \%$ runner bean in the same row recorded the minimum weed density and all other planting patterns proved inferior in reducing weed density. This was slightly different from the findings of Chimpomho et al. (2015) ${ }^{[3]}$ who said that same row planting of inter crops reported higher weed density and biomass due to the open spaces available in between the rows which could facilitate the weed growth. However, in case of the present investigation, the growth of runner bean was favoured due to same row inter cropping and almost covered the inter row spaces thereby suppressing the weeds. In subsequent stages, sole runner bean was equally effective in reducing weed density. This was due to the smothering nature of runner bean which helped in covering the ground with its lush foliage and thus not allowing the germination and establishment of the weeds. The total density was maximum in sole maize with a value of $61.4 / \mathrm{m}^{2}$ at harvest because maize is a wide spaced crop, with high fertilizer requirement and slow growth habit during the early stages from germination to knee high stage which made it highly congenial for the growth and establishment of the weeds. The same trend was seen in case of the total weed dry weight. These findings were in 
agreement with the findings of Bhuvaneshwari et al. (2002) [2], Sharma et al. (2013) ${ }^{[11]}$ and Choudhary et al. (2014) ${ }^{[4]}$.

The pre- emergent application of pendimethalin @ $1.0 \mathrm{~kg} / \mathrm{ha}$ with one manual weeding at 25 DAS observed the minimum total weed density of $2.2 / \mathrm{m}^{2}$ and dry weight of $55.2 \mathrm{~g} / \mathrm{m}^{2}$ at harvest. However, the maximum weed density of $72.9 / \mathrm{m}^{2}$ and dry weight of $319.4 \mathrm{~g} / \mathrm{m}^{2}$ at harvest was observed in the weedy check plot. This was in clear confirmation with the findings of Behera et al. (1998) ${ }^{[1]}$ and Bhuvaneshwari et al. $(2002)^{[2]}$.

The maximum weed control efficiency was obtained in pendimethalin $1.0 \mathrm{~kg} / \mathrm{ha}+$ one manual weeding at all stages of crop growth and the maximum weed smothering efficiency of $81.3 \%$ was obtained in maize $100 \%$ + runner bean $100 \%$ in same row at harvest and was in agreement with the findings of Bhuvaneshwari et al. (2002) ${ }^{[2]}$.

\section{Effect of treatments on nutrient content and uptake of the system}

The nitrogen, phosphorous and potassium content in the grain as well as stover was obtained in maize $100 \%+$ runner bean $50 \%$ in separate rows and the minimum was maize $100 \%+$ runner bean $100 \%$ in same row. Similar findings were reported by Choudhary et al. (2014) ${ }^{[4]}$ who said that this was due to better availability and supply of $\mathrm{N}$, wide range of microbes in the plant rhizosphere to mobilize the inherent $\mathrm{P}$ and $\mathrm{K}$, this increasing its availability. However, maximum uptake was observed in sole maize due to its higher yield.

For runner bean, maize $100 \%$ + runner bean $100 \%$ in same row gave significantly higher pod and haulm nutrient content and the maximum uptake of $\mathrm{N}, \mathrm{P}$ and $\mathrm{K}$ was in sole runner bean due to its higher yield.

However, among the weed management practices, the percentage nitrogen, phosphorous and potassium was highest in $\mathrm{W}_{3}$ (pendimethalin @ $1.0 \mathrm{~kg} / \mathrm{ha}$ pre- emergent + manual weeding at $25 \mathrm{DAS}$ ) and lowest in $\mathrm{W}_{5}$ (weedy check) in grain and stover of maize and pod and stalk of runner bean. This was in agreement with the findings of Choudhary et al. (2014) [4].

Among the planting patterns, the maximum nutrient content and uptake of nitrogen, phosphorous and potassium by weeds was observed in sole maize at harvest because of the congenial condition for weed growth which also resulted in the higher total weed density and dry weight.

Among the weed management practices, the maximum nutrient content and uptake of nitrogen, phosphorous and potassium was found in the weedy check plot was due to higher density and dry weight of weeds. Similarly, the minimum nutrient content and uptake was observed in pendimethalin@1.0 kg/ha pre- emergent + manual weeding at 25 DAS.

\section{Conclusion}

\section{Weed dynamics}

Among the planting patterns, the minimum weed density and dry weight of $39.9 / \mathrm{m}^{2}$ and $59.8 \mathrm{~g} / \mathrm{m}^{2}$ respectively was recorded in maize $100 \%+$ runner bean $100 \%$ in the same row and this gave the maximum weed smothering efficiency of $81.3 \%$. The application of pendimethalin $1.0 \mathrm{~kg} / \mathrm{ha}+$ one manual weeding at 25 DAS gave the minimum weed density and dry weight of $2.2 / \mathrm{m}^{2}$ and $55.2 \mathrm{~g} / \mathrm{m}^{2}$ which also gave the maximum weed control efficiency of $82.5 \%$ at harvest.

\section{Nutrient studies}

The maximum nutrient of content in the maize grain and stover was recorded in maize $100 \%$ + runner bean $50 \%$ in separate rows. However, maximum uptake was observed in sole maize due to its higher yield. The maximum nutrient content and uptake by maize was observed with the application of pendimethalin $1.0 \mathrm{~kg} / \mathrm{ha}+$ one manual weeding at 25 DAS.

For runner bean, maize $100 \%$ + runner bean $100 \%$ in same row gave significantly higher pod and haulm nutrient content and the maximum uptake of $\mathrm{N}, \mathrm{P}$ and $\mathrm{K}$ was in sole runner bean due to its higher yield.

\section{References}

1. Behera B, Singh GS, Pradhan PC, Senapati PC. Weed management in runnerbean (Phaseolus coccineus) + maize (Zea mays) intercropping under rainfed condition. Indian Journal of Agricultural Sciences. 1998; 68(10):697-698.

2. Bhuvaneshwari J, Muthusankaranarayanan A, Avudaithai S. Weed smothering effect of inter cropping in maize. Madras Agricultural Journal. 2002; 89(10-120):714- 718.

3. Chipomho J, Mapope N, Masuka B, Ngezimana W, Chipomho C. The influence of cropping systems and maize- bean intercrop spatial patterns on companion crop yield, weed density and biomass. International Journal of Agriculture and Crop Sciences. 2015; 8(5):697-705.

4. Choudhary VK, Dixit A, Kumar PS, Chauhan BS. Productivity, Weed Dynamics, Nutrient Mining, and Monetary Advantage of Maize - Legume Intercropping in the Eastern Himalayan Region of India. Plant Production Science. 2014; 17(4):342-352.

5. Coble HD. Future directions and needs for weed science research. Weed Technology. 1994; 8:410-412.

6. Ghanbari-Bonjar A. Intercropped wheat and bean as a low- input forage. PhD thesis. Wye college. University of London, 2000.

7. Jamshidi K, Yousefi AR, Oveisi M. Effect of cowpea (Vigna unguiculata) intercropping on weed biomass and maize (Zea mays) yield. New Zealand Journal of Crop and Horticultural Science. 2013; 41(4):180-188.

8. Kalloo G. Runnerbean (Phaseolus coccineus 1.). (in) Genetic Improvement of Vegetable Crops, 1993, 405-7. Kalloo G and Bergh B (Eds), Pergamon Press, New York.

9. Padhi AK, Panigrahi RK. Effect of intercrop and crop geometry on productivity, economics, energetic and soil fertility status of maize (Zea mays)-based intercropping system. Indian Journal of Agronomy. 2006; 51(3):174177.

10. Patel VJ, Upadhyay PN, Zala SV, Patel BD. Residual effect of herbicide applied as alone and mixture of kharif maize succeeding rabi oat and mustard. Indian Journal. Weed Science. 2006; 38(3-4):258-262.

11. Sharma RC, Banil P. Baby Corn - Legumes Intercropping System: II Weed Dynamics and Community Structure. NJAS - Wageningen Journal of Life Sciences, 2013; 67:11-18.

12. Uchino H, Iwama K, Jitsuyama Y, Yudate T, Nakamura $\mathrm{S}$. Yield losses of soybean and maize by competition with interseeded cover crops and weeds in organic-based cropping systems. Laboratory of Crop Science, Department of Botany and Agronomy, Graduate School of Agriculture, Hokkaido University, Sapporo, Japan 060-8589, 2008. 